\begin{tabular}{|ccc}
\hline Sournals & $\begin{array}{c}\text { INTERNATIONAL JOURNAL OF } \\
\text { ORGANIZATIONAL LEADERSHIP }\end{array}$ & $\begin{array}{c}\text { INDUSTRIAL } \\
\text { MANAGEMENT } \\
\text { INSTITUTE }\end{array}$ \\
\hline \hline
\end{tabular}

\title{
Nexus between workers' remittances, unemployment, labor migration and economic growth in Pakistan
}

\author{
Muhammad Asad $^{1}$, Shujahat Haider Hashmi ${ }^{2 *}$, Saadia Yousaf ${ }^{3}$ \\ ${ }^{1}$ MUST, Mirpur (AJ\&K), Pakistan \\ ${ }^{2,3}$ CUST, Islamabad, Pakistan
}

\begin{abstract}
Keywords:

Workers' Remittances, Unemployment, Economic Growth

Received

09 May 2016

Received in revised form

01 August 2016

Accepted

18 August 2016

Correspondence:

shujahat@cust.edu.pk

This study examines the relationship between workers' remittances and economic growth along with labor migration in Pakistan. The study also investigates the relationship between workers' remittances and unemployment and captures the interaction between unemployment and economic growth. Annual time series data from 1975 to 2010 is used for analysis. Following this, Johansen and Juselius' (1990) co-integration technique and recursive simultaneous equations model have been applied for analysis. Multivariate and Bivariate Co-integration approach shows that there exists long-term relationship between workers' remittances and economic growth in Pakistan. Bivariate co-integration presents that economic growth has long-run relationship with labor migration and unemployment. There is long-run relationship between workers' remittances and unemployment and human capital has long run association with workers' remittances. Granger Causality test shows that there exist unidirectional causality between workers' remittances and economic growth. Unidirectional causality runs from labor migration and unemployment to economic growth. Similarly, unidirectional causality runs from workers' remittances to unemployment level in country. The recursive OLS results manifested that workers' remittances have significant positive impact on consumption and consumption in turn has significant positive effect on economic growth.
\end{abstract}

CAIMI Journals

Workers' remittances are the earnings of overseas nationals which they send back to their home country. Money remitted by the migrant labor force constitutes the second largest component of the foreign exchange receipts in most of developing countries. These remittances play a vital role in boosting the economic growth of a country. As compare to other sources of foreign exchange inflows (foreign aids, foreign direct investment, and foreign loans) foreign remittances are considered crucial for consistent and rapid economic growth because of its 
stability of inflow. Addison (2004) stated that amount remitted by oversea workers follow a stable pattern. This study is intended to analyze the relationship between workers' remittances and economic growth. The inflow of foreign remittances due to the openness of world economy and growing trend of labor force mobility round the globe develops speedily in positive way. According to World Bank development indicators, the worker's remittances to developing countries through official channels are 231 Billion dollar in 2009 and become 243 Billion dollar in 2010. In many developing countries, the flow of foreign direct investment has gone down sharply because of economic recession. On other hand, during last 5 years the flow of workers' remittances develops positively.

Deficit of foreign exchange reserves and import bills are the main problems for developing countries. These countries need the hefty amount of foreign exchange reserves to pay the import bills regularly in order to maintain the pace of economic growth and development. The inflow of foreign currency through overseas earning provides the opportunities to developing countries to resolve the problem of balance of payment. In Pakistan, the balance of payment situation is quite unfavorable. Pakistan import bill was 40.4 Billion dollar; following this, its overall inflows of foreign exchange (from exports, FDI, workers' remittances, and foreign aid) are 37.1 Billion dollar. Out of these total inflows, 26 percent is related to remittances from overseas Pakistani.

Workers' remittances constitute a significant component of much needed resources for economic development in developing countries. Fayissa and Nsiah (2010) reported that the foreign remittances are the key factor for the consistent and rapid economic growth and provide a stream to finance development projects, augment the investment level, and assist the countries in controlling the liquidity issues. Increase in workers' remittances result increased consumption and investment in the home country of the oversea nationals. Migrants' remittances push up the income level, which lead to increase in the purchasing power. This in turn increases the domestic production. Increase in investment, consumption, and domestic production all are main determinants of economic growth. Foreign remittances also help for poverty alleviation in developing countries. Addison (2004) inferred from their research study that remittances promote the economic growth. Although most parts of the workers' remittances are used by his family on daily consumption purposes, some parts are used for houses construction and real estate investments. Only a very small portion is used for saving and productive purposes.

Strong and effective mechanism and appropriate policies are needed to reap the benefits of workers' remittances. Sattar and Iqbal (2005) argued that foreign remittance have positive impact on long run economic growth; however, the right policies can channel these remittances flow in more productive investment activities. They reported that the remittances are the second most important source for economic growth in Pakistan. Adenutsi (2011) reported that financial development promote the economic growth but this will only be achieved in a better way if it succeed to attract plentiful migrants remittances (Non debt external capital).

South Asian countries are marked as the biggest market of cheap labor force. These countries' export base is not much broader. Pakistan is one of the major exporters of the labor force in South Asia. Excessive labor force usually remains underemployed; due to this, the average labor productivity and per capita income go down. Therefore, outflows of labor force 
in rest of world make labor force operational and better employed. In turn, this provides stream of resources which are vital for their home country's economy. Gammage (2006) argued that emigration of labor from a country to ensure the inflow of remittances has strategic importance for those countries which have the limited export base and excessive bank of labor force. It helps those countries by augmenting to their foreign exchange reserves, reducing the poverty intensity and providing new stream of capital.

Workers' remittances affect economic growth positively in both short and long run. FDI is linked with the economic and political conditions in the countries but migrants' remittances remain stable and sometime even show increasing trend during bad economic and political conditions. This is due to emotional attachment and moral duty of emigrants to finance the remainder family in home country. Ratha (2005) argued that Workers' remittances are major source of external funding when foreign private investment inflow declines in a country. Magnitude of remittances flow in low income countries is greater than that in middle income countries. In developing countries the remittances are the stable source of foreign exchange even during the bad economic period because the major motive of overseas workers behind these remittances is fulfilling the consumption need of the families in home country; so that they can maintain the minimum subsistence level even during the hard time. Das and Chowdhury (2011) stated that there exist long run positive relation between remittances and GDP but the magnitude of remittances to GDP is very small. Remittances affect the economic growth in the long run but in case that the most part of remittances are used for consumption the extent of affect will be very small. The size of affect will only be large if remittances are directed to investment activity in the country. So, directing these inflows of emigrants' earnings to proper channel is of primary importance for the pace of economic growth.

The remittances are major source of foreign exchange reserve and non-debt foreign capital for developing countries. In Pakistan the inflow of workers' remittances constitutes the second major component of foreign exchange receipts. Therefore, it is one of the components significantly contributing to economic growth of Pakistan. This study intended to analyze the relationship between workers' remittances and economic growth of Pakistan. On other side, the study has captured the relation between labor migration and economic growth. As previous research work has also overlooked the migration interaction with economic growth. The migrants' remittances interaction with unemployment level in the country is a matter of attention. These remittances can stream line the unemployment level in country by boosting the economic activities and may also cause the voluntary unemployment due to unnecessary reliance by remainder family of migrant workers. But the relationship of unemployment with workers' remittances and economic growth is not captured by previous studies. Therefore, this study has attempted to capture this relation too.

\section{The Literature Review}

The economic growth and its determinants are being studied since a long time. The researchers have studied it in sufficient depth. Migrants' remittances are global phenomena. Due to increased openness of economy of globe people from their origin country travel to far away for employment. They earn there and remit to their families in home country. Although workers' remittances are enhancing consumption power, savings and resources to finances investment in 
recipient country; it is not much studied in relation with economic growth in past. Since last decade the workers' remittances is continuously debated by many researchers and provided empirical evidences.

Fayissa and Nisha (2008) explored the workers' remittances relationship and influence on economic growth of Africa; they argued that Remittances have positive and statistically significant impact on the economic growth. The investment in Human and physical capital is positively associated with economic growth. Foreign aid has insignificant negative effect on economic growth. Openness of the economy positively affect but not significantly. FDI affect the economic growth in positive way. The result for political freedom shows that poor governance in the African countries is an obstacle to economic growth. Initial per capita income has positive significant impact on current level of economic growth of the country. Adenutsi (2011) conducted study in Ghana to explore the financial development relationship with worker' remittances and remittances influence the economic growth. They founded that financial developments granger causes the foreign remittances. Well-developed financial system in country promotes the foreign remittances. Financial development in itself is driver of economic growth. Workers' remittances have positive and significant impact on economic growth both in short and long run. Jackman, Craigwell, and Moore (2009) explored the economic growth fluctuations and remittance in small Island developing states. They argued that the rise in remittances to GDP ratio has stabilizing impact on consumption, output, and investment; but remittances volatility is significantly and positively associated with increased economic volatility. Along with the control variables in the model, the remittances fluctuation does affect the investment activity which challenges the notion that foreign remittances are only used for consumption purposes. In period of economic expansion, the remittances and volatility of remittances have smoothing effect on output and investment but in time of economic downturn, its affect is insignificant. However, in case of consumption the remittances affect is significant only in time of economic recession.

Sattar and Iqbal (2005) attempted to explore the contribution of workers' remittances in economic growth of Pakistan. They founded positive highly significant relationship between workers' remittances and real GDP growth. This maps that higher remittance inflow lead to higher economic growth. Public and private investment is also significantly and positively associated with GDP growth. Higher investment activity results in higher economic growth. Inflow of remittances increases the quantum for investment purpose. Inflation and external debt has negative impact on economic growth. Change in term of trade is also negatively associated with real GDP growth.

Jawaid and Raza (2012) reported that there is long run significant positive relationship between workers' remittances and economic growth in Korea and significant negative relation in china. The negative influence of workers' remittances on pace of economic growth in China could be due to voluntary unemployment. In Korea, the relationship between remittance and economic growth in short run is also positive and significant but in China this relation is insignificant. The results of granger causality analysis confirm that there is unidirectional causality from migrants' remittances to economic growth both in China and Korea. Das and Chowdhury (2011) founded that there is long run relationship between remittances and GDP but this relationship is weakly significant. This shows that remittances in these countries are 
used for consumption. Therefore, remittance, even if these are used for consumption, will affect the economic growth. Nevertheless, the magnitude of effect will be small. The coefficient of impact of remittances on GDP will only be large when the remittances are used for investment activities in recipient country. Ahortor and Adenutsi (2009) argued that along with the control variables, migrants' remittances have positive impact over the long run in small developing economies. The results add to the strength of ideology of remittances optimistic school that workers' remittances contribute more efficiently to economic growth of those countries where financial system are underdeveloped and are incapable to mobilize the resources to finance investment projects.

Glytsos (2005) inferred from empirical evidences that the remittances in developed countries like Europe have less or marginal effect on economic growth but in developing countries where it is the major source of covering the imports bill, the remittances has highly significant impact on economic growth. Migrants' savings are channeled to productive use even if the migrant workers themselves do not invest directly because these savings are held with bank by migrants or their remainder families in home country; so, banks are in position to direct these resources for productive use by extending the loan. Fayissa and Nsiah (2010) investigated the promotional impact of migrants' remittances on economic conditions in Latin American countries. They reported that the remittances have significant positive effect on GDP per capita of Latin economies. Investment in human and physical capital has positive impact on GDP per capita. Foreign Aid and other foreign financial inflows have negative association with GDP. Trade openness has positive but not significant effect on GDP and FDI has significant positive relationship with GDP.

Karagoz (2009) studied the remittances and economic growth interaction in Turkey. He founded that there is one co-integration vector which shows at least one important relation between variables over long run. The results of OLS between per capita GDP and remittances and other control variables shows that there is negative relationship between GDP per capita and remittance as ratio of GDP. Exports and gross domestic product has positive impact on per capita GDP. Remittances vary greatly from investment and exports in essence of their motivation and their effects. In case of Turkish, remittances do not look like as the source of capital for economic growth; that is why its impact on economic growth is negative. The possible reason for this negative relation may be the voluntary unemployment. Ahmed, Zaman, and Shah (2011) investigated the workers' remittances influence on the level of economic growth in Pakistan. They argued that foreign remittances and lag term of GDP are significant and positively associated with economic growth in both short and long run. Exports are also significant and contributing positively to economic growth over long run. Money supply is found insignificant to contribute to growth. Low error correction model coefficient shows that recovery procedure in Pakistan economy is quite slow.

Yasmeen et al. (2011) conducted study in Pakistan to explore the migrants' remittances effect on investment in private sector and consumption level. They founded that private investment positively depends on GDP and worker remittances. Total consumption is also positively associated with GDP and remittances. Azam and Khan (2011) investigated the remittances and economic growth relation in Azerbaijan. They reported that remittances have significant and positive impact on economic growth of Azerbaijan and Armenia; so, conducive 
polices are required to attract increased remittances in future to keep the economy growing. Giuliano and Ruiz Arranz (2009) explored the remittances effect on economic growth and their analysis was based on 100 developing countries. The result of their study indicated that there is strong significant positive relation between growth and remittances and negative interaction between remittances and financial development. This shows that marginal effect of remittances decreases with the financial development in the country. Financial development also has positive relation with economic growth. Catrinescu, Ledesma, Piracha, and Quillin (2009) conducted a study on 169 countries to explore effect of workers' remittances through institutions on economic conditions. They founded that there is a positive long run relationship between remittances and economic growth and lag term is also significant positive; this shows that the trend of remittances' impact will continue in future.

Jawaid and Waheed (2011) founded that there is a significant positive effect of term of trade of economic growth in country and the volatility of term of trade also has significant positive association with economic growth. Wong (2010) studied the trade conditions and economic growth in Japan and Korea. The findings displayed that GDP per capita and term of trade are mutually formed and remittances positively affect the economic growth. Increase in term of trade volatility result in decrease in GDP per capita. Increase in oil prices lead to decrease in GDP. Moreover, the main contributor to GDP per capita in Japan and Korea differ from each other. Ratha (2005) reported that workers' remittances are major source of external funding when foreign private investment inflow declines in a country. Magnitude of remittances flow in low income countries is greater than that in middle income countries. In developing countries, the remittances are the stable source of foreign exchange even during the bad economic period because the major motive of overseas workers behind these remittances fulfills the consumption need of the families in home country; so that they can maintain the minimum subsistence level even during the hard time. Even though the motive behind these remittances is investment, their inflow remains less volatile as the overseas workers consider it better to invest in their home country.

Maimbo (2006) conducted study in Somalia to explore the effects of migrants' remittances. He argued that workers' remittances have significant positive effect on the education level in Somalia. School enrollment rate of children of overseas workers' families is much higher as they urge their families to whom they send their money to get the children educated. The study findings showed that in Somalia which is the poorest country of the world and much conflicted area, the remittances help people to survive in the politically unstable time period. However, remittances cannot contribute to long run economic growth by itself. Political stability is prerequisite for better effect translation of remittances on economic growth in short and long run. Jongwanich (2007) investigated the migrants' remittances influence on economic conditions and level of poverty in developing countries of Asia and Pacific. They founded that worker remittances have significant positive impact on poverty reduction by enhancing the income, consumption level, and easing the problem associated with poor access to capital. It also affects economic growth positively by working through investment in home country and building the human capital. Adams and Page (2005) founded that international migration and remittances both lead to decrease in the level depth and severity of poverty level in developing countries. Inequality has positive relation and magnitude with poverty. At the beginning of this 
century, it was established that about 175 million people, which is roughly $3 \%$ of the world population, lived and worked outside of their home country.

De Haas (2005) explored the influence of migration of labor across border and money remitted on economic growth. He reported that international migration and migrant remittances could have positive contributing impact on the development and living pattern of the recipient countries. However, unattractive investment environment and increased complications on immigration stop their high developmental impact. A country cannot progress if it has low literacy rate and inappropriate infrastructure to cure for the health of masses. Its economy growth accelerate when that country concentrate and allocate significant funds to education and health of population. Johnson (2011) founded that investment to build and improve the human capital has positive effect on pace of economic growth. He argued that skilled labor force have better abilities to utilize and convert the resource in effective way which help the economy to grow at a better pace. Khan (2005) argued that investment in human capital has positive impact on economic growth of the country.

Buckley and Hofmann (2012) conducted a study in Tajikistan to explore whether remittances are effectual measure of economic development. They reported that there is negative relation of financial security, household's material wealth and entrepreneurial activity with remittances receiving and these measures reduces with passage of time. Imai, Gaiha, Ali, and Kaicker (2014) analyze that how remittances contribute to economic growth and poverty reduction. Their study focused on 24 Asian and Pacific countries. They founded that remittances contribute to economic growth in a positive way. However, fluctuation in foreign capital flow drive to production shocks in recipient country. Inflow of earnings of overseas employees to their home country has significant positive direct impact on reducing the level of poverty. Rahman, Mustafa, Islam, and Gharana (2006) founded that real per capita GDP growth has long run contributory relation with per capita employment. Foreign direct investment growth, migrants' remittances growth, and export growth also augment to employment opportunities. However, these explanatory variables have not the significant relation with employment in Bangladesh. Posso (2012) investigated whether recruiting the remittances have effect of reducing labor force participation. They founded that recruiting the remittances have positive impact on labor force participation in recipient countries. They argued that this effect is due to the fact that migrants' family in home country show responsibility to bear the cost associated with the migration. Therefore, they are prone to actively participate in working. Secondly, the inflow of remittances provide the opportunity to invest more in countries where access to credit is difficult; so it in turn create more employment opportunities and engage more population in work.

Georges and Pozo (2010) reported that workers' remittances have positive impact on schooling of children. Therefore, Migrant remittances contribute to human capital development. Following this, the inspiration of non-migrant household to migrate due to the life style that enjoyed by migrant families will result to lower their inspiration to get their children educated. However, migrants' remittances contribute positively in education level of Haiti as it also has increasing effect on income level of household working in country. Barai (2012) explored the developmental impact of remittances in Bangladesh. He argued that foreign migration and inflow of remittances to home country positively affect the level of 
employment and raise the level of national savings capital stock and investment activities. Workers' remittances contribute to improve the life standard of their families in home country as they are in position to better consumption, health and education facilities.

Airola (2007) showed that households who receive remittances utilized the most of this money for acquiring long lasting assets, healthcare, and constructing the home buildings. They spend a very little portion on daily consumption and food. Study founded the insignificant impact of these remittances on education expenditure. Campbell (2006) found that real foreign income is positively associated with remittance to home country. Real local income is also positively related with workers' remittances which indicate that Barbados economy should grow on a consistent pace to ensure the vital inflow of remittances. Increase in exchange rate has negative impact on the workers' remittances inflow. Unemployment is positively associated with migrants' remittances. Shahbaz (2010) founded that economic growth in country has positive impact on unequal distribution of income level both in short and long run. The results reported negative association of income disparity with level of human capital development and unemployment. Remittances effect the unequal distribution of income positively in long run but negatively in short run. Coefficient of remittances impact on income distribution difference is negative.

Zuniga (2011) studied to explore the level of workers' remittances assistance in economic growth. His analysis was based on 122 developing countries. He founded that remittances carry the positive influence on the level of economic growth but this impact is not much significant. The intensity of the effect remains unchanged even after incorporating the institutions variable in the analysis. The impact of remittance on growth of economy varies from region to region. Eastern European region is on top with regard to the intensity of remittances impact and remittance influence in African economies is insignificant. Arun and Ulku (2011) investigated the factors which induce the remittances by workers to their home country. They founded that the level of income, employment situation, and education level are positively associated with magnitude of remittance amount remitted to home country. In context of rootedness in UK, those married migrants who have children and parent in UK, have negative relation with the remittances to country of origin. Duration of stay in hosted country also showed negative association. Results for savings, land acquirement, and loan settlement have shown positive association with remittances.

Niimi, Pham, and Reilly (2009) reported that migrants remit their earnings back to home with motive to support their family against economic uncertain situations. Level of earnings of migrants in host country is founded positively related with the inflow of remittance. Education level of migrants also has positive influence on remittances. Nishat and Bilgrami (1991) conducted study in Pakistan to explore the influence of money remitted by overseas workers on economy of Pakistan. They reported that workers' remittances affect the level of GNP positively and significantly in Pakistan.

The recent studies have also explored the effect of workers' remittances on economic growth and development. Chowdhury (2016) found a positive effect of workers' remittances on economic growth and suggested that government should emphasize more on financial development to bring effectiveness in transfer of foreign money. Jebran, Abdullah, Iqbal, \& Ullah (2016) also empirically tested a positive long-run and short-run effect of workers' 
remittances on per capita GDP of Pakistan. However, Adams and Klobodu (2016) emphasized that regime type plays an important role and found positive moderating effect of democratic and stable government upon the relationship between workers' remittances on economic growth. Kratou and Gazdar (2016) emphasized the role of financial development and quality of financial institutions and documented a positive effect of workers' remittances on economic growth in the short-run depending upon the role of financial development.

Review of empirical literature provided that micro and macro level studies had been conducted on workers' remittances and economic growth. However, literature gap exist in context of Pakistan for short-run and long-run relationship between worker remittances and economic growth along with the labor migration. The relationship between workers' remittances and unemployment is also not yet established. Therefore, this study has intended to fill this literature gap by looking into short-run and long-run relationship between workers' remittances and economic growth along with labor migration. The study will also investigate the relationship between workers' remittances and unemployment level in the country.

\section{Research Hypotheses}

On basis of reviewed empirical literature, following hypotheses are formulated:

$\mathbf{H}_{\mathbf{1}}$ : There is significant relationship between workers' remittances and economic growth.

$\mathbf{H}_{2}$ : There is significant positive impact of workers' remittance on economic growth.

$\mathbf{H}_{3}$ : There is significant relationship between labor migration and economic growth.

$\mathbf{H}_{\mathbf{4}}$ : There is significant relationship between unemployment level and economic growth.

$\mathbf{H}_{5}$ : There is significant relationship between workers' remittances and unemployment level.

\section{Method}

This study aimed to analyze the workers' remittances and economic growth in Pakistan. Annual time series data from 1975 to 2010 is used for analysis. Data used in the study is collected from various sources. The sources include the World Bank database (world development indicators), the World Economy and International Labor Organization. The variables used in study are Gross Domestic Product (GDP), Workers' Remittances (REM), Labor Migration (LMR), Unemployment Rate (UEM), Government Expenditure (GXP), Human Capital Development (HCD), Household Consumption (HC), Investment (INV), and Domestic Savings (DS). GDP is used as proxy for economic growth in the country and will be measured as GDP per Capita in US Dollars (Karagoz, 2009). The workers' remittances are measured as percentage of GDP in US dollar. To measure the unemployed labor force, the unemployment rate is used as proxy and this represent the unemployed labor force as percentage of total labor force. Domestic savings are used as percentage of GDP. Outflow of labor force across the country border is used as proxy to measure the labor migration. Human capital development is measured as secondary school enrollment as percentage of total population (Jawaid \& Raza, 2012). Government expenditure on final goods and services as percentage of GDP is used to proxy the government expenditure. Final household consumption of goods and services as percentage of GDP is used as proxy for consumption. Gross fixed capital formation as percentage of GDP is used as proxy for investment. Co-integration method of analysis is used to derive the results of the study. 
Unit root test is applied to analyze the state of stationarity of the variables. Augmented Dickey Fuller Test and Philip-Perron test have been employed for stationarity. Co-integration analysis is applied to identify the long-run co-movement or relationship among different variables which are the focus of the study. Co-integration requires that all the time series should be integrated of same order and assumes that even if two time series are individually non-stationary, a linear combination of two might be stationary. Co-integration does not study the cause and effect relationship. It just studies the long-run co-movement or relationship and is based on empirical evidence. There might be some economical reasoning of this relationship and there might not be any economic reasoning of this relationship. The method itself does not address any cause and effect relationship. Johnson and Juselius (1990) propose two likelihood ratio tests for the determination of the number of co-integrated vectors. One is based on the trace statistic which tests the null hypothesis of $\mathrm{r}$ co-integration vectors against the alternative of $r$ or more co-integration vectors. The second test is the maximal Eigen value test which evaluates the null hypothesis that there are most $r$ co-integration vectors against the alternative of $r+1$ co-integration vectors.

Once a co-integration test has found any long-run relationship then next aspect to look at is the lead lag relationship between variables; for this purpose, Granger Causality Test is used. Granger Representation Theorem states that if two variables are co-integrated then causality must exist in at least one direction. Co-integration examines the co-movement among the time series. It does not identify the lead lag relationship. Granger causality is used to determine the lead lag relationship. If the lead series is known then lag series can be predicted. Granger causality reports that which series leads the other series or which variable exerts its pressure on other variable. If causality is found in one direction then it will be called as unidirectional causality. Unidirectional causality means that information is flowing from one series to the other series. If the lag relation is found from both direction then it means that information is flowing from both sides and both the series are exerting their pressure on each other. Long-run co-movement and lead lag relationship among the variables exist then sometimes disequilibrium may occur between co-integrated series. This disequilibrium rectifies itself with passage of time by converging to normal movement path. To study this disequilibrium in the co-movement of series Vector error correction model is used to study both disequilibrium and correction of deviation.

Once the relationship between worker remittances and economic growth is analyzed, then for analyzing the impact of worker remittances on economic growth the "Recursive Simultaneous Equations Model" will be used. This model requires that every earlier equation be estimated first for having the estimated/predicted value of the dependent variables involved. Then, that predicted value is used for determination of the subsequent dependent variable. As remittances affect the level of consumption and saving in the country then consumption and saving in turn influence the GDP i.e. economic growth level; so, the following recursive simultaneous equation will be used for estimation of impact of workers' remittances on economic growth. Figure 1 displays the relationship between workers' remittance, household consumption, domestic investment, and economic growth. 


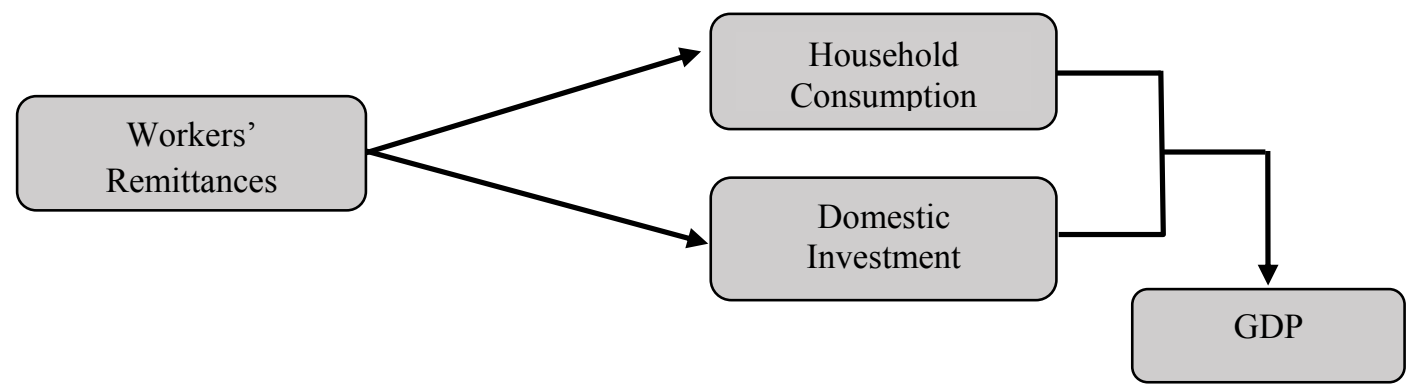

Figure 1. Recursive model

$$
\begin{aligned}
& \mathrm{HC}=\beta_{\mathrm{o}}+\beta_{1} \mathrm{REM}+\mathrm{u}_{\mathrm{t}} \\
& \mathrm{INV}=\beta_{\mathrm{o}}+\beta_{1} \mathrm{REM}+\mathrm{u}_{\mathrm{t}} \\
& \mathrm{GDP}=\beta_{\mathrm{o}}+\beta_{1} \mathrm{HC}^{\wedge}+\beta_{1} \mathrm{INV}^{\wedge}+\mathrm{u}_{\mathrm{t}}
\end{aligned}
$$

In above equations $\mathrm{HC}$ is household consumption. INV is domestic investment. GDP is gross domestic product per capita $\mathrm{HC}^{\wedge}$ is predicted value of household consumption and $\mathrm{INV}^{\wedge}$ is predicted value of domestic investment.

\section{Results}

Descriptive statistics during period from 1975 to 2010 of the variable used in the study are shown in Table 1. The average domestic savings (DS) were $11.98 \%$ of the GDP. The possible deviation from average was 4.023. Maximum level of domestic savings during the observed time period was $17.61 \%$ and minimum level was $4.68 \%$. Average annual GDP per capita was 465 dollar. Dispersion from average level was 106.82. Maximum level of GDP per capita during this period was 668.54 and minimum level was 295.38. Government expenditures (GXP) were $11.18 \%$ of GDP. Dispersion from average level was 2.24. Maximum level of government expenditure was $16.78 \%$ of GDP while at minimum level these were $7.78 \%$.

\begin{tabular}{|c|c|c|c|c|c|}
\hline Variables & Mean & Median & SD & Max & Min \\
\hline DS & 11.98 & 11.23 & 4.02 & 17.61 & 4.68 \\
\hline GDP & 465.44 & 479.94 & 106.83 & 668.54 & 295.38 \\
\hline GXP & 11.18 & 11.01 & 2.24 & 16.78 & 7.78 \\
\hline HCD & 31.51 & 25.28 & 13.51 & 51.35 & 16.23 \\
\hline LMR & 116.49 & 111.95 & 56.94 & 233.90 & 56.20 \\
\hline REM & 4.87 & 4.52 & 2.31 & 10.24 & 1.45 \\
\hline UEM & 4.92 & 4.65 & 1.59 & 8.30 & 2.60 \\
\hline
\end{tabular}

Table 1

Descriptive Statistics

Human capital development (HCD) depicted by secondary school enrollment was $31.52 \%$ of total population on average. The dispersion from average was 13.51. The maximum level of secondary school enrollment was $51.35 \%$ and minimum level was $16.236 \%$. Average Labor migration (LMR) was 116.49 thousand. The dispersion from average was 56.20. The maximum level of labor migration was 233.91 thousand and minimum level was 111.96 thousand. Average inflow of workers' remittances (REM) was $4.87 \%$ of GDP. The dispersion from average level was 2.32 . The maximum level of workers' remittances inflow was $10.25 \%$ of GDP and minimum level was $1.45 \%$. The average unemployment rate (UEM) was $4.92 \%$ of 
total labor force. The dispersion from average was 1.59. The maximum level of unemployment was $8.30 \%$ of total labor force and minimum level was 2.60

The results of correlation Matrix in Table 2 present that GDP was positively correlated with workers' remittances, labor migration, domestic savings, and human capital development. GDP was negatively correlated with unemployment level in country and government expenditure. The correlation coefficient between GDP and unemployment, GDP and domestic saving, GDP and human capital was significant. Correlation analysis was weak technique as it did not discuss the lead lag relationship. In order to take better picture of the affairs we performed cointegration and Granger causality test to further investigation.

Table 2

Correlation Matrix

\begin{tabular}{clcccccc}
\hline No. & Variables & 1 & 2 & 3 & 4 & 5 & 6 \\
\hline 1 & REM & 1 & & & & & \\
2 & LMR & 0.43 & 1 & & & & \\
3 & UEM & -0.55 & 0.67 & 1 & & & \\
4 & DS & 0.63 & 0.55 & 0.66 & 1 & & \\
5 & GXP & 0.10 & -0.29 & -0.67 & -0.13 & 1 & 0.56 \\
6 & HCD & 0.55 & 0.41 & 0.54 & 0.41 & -0.56 & -0.30 \\
7 & GDP & 0.69 & 0.51 & -0.63 & 0.50 & & \\
\hline
\end{tabular}

Co-integration analysis required that time series should be integrated of the same order; so, in first step Stationarity of the variables has been tested. Table 3 shows that the time series are not stationary at levels. However first difference of the logarithmic transformations of the series were stationary. Therefore, all series were integrated at first difference. Dickey-Fuller tests suppose that the errors are statistically independent and have a constant variance. This may not be the case with some of the data used here so the less restrictive Phillipe Perron test was used to test the Stationarity of a time series. Table 3 represents the unit root and lag length criteria.

Table 3

Unit Root and Lag Length Criteria

\begin{tabular}{|c|c|c|c|c|c|}
\hline Variables & ADF Level & ADF 1st Dif & PP Level & PP 1st Dif & \\
\hline Ln DS & -2.63 & -6.84 & & & \\
\hline Ln GDP & -0.90 & -4.64 & & & \\
\hline Ln GXP & -1.61 & -7.88 & & & \\
\hline Ln HCD & -0.31 & -4.64 & & & \\
\hline Ln LMR & -0.57 & -4.94 & & & \\
\hline Ln REM & -1.53 & -4.91 & & & \\
\hline Ln UEM & -1.59 & -6.83 & & & \\
\hline Ln HC & -1.93 & -5.60 & & & \\
\hline $1 \%$ Critical Value & -3.63 & -3.63 & & & \\
\hline $5 \%$ Critical Value & -2.94 & -2.94 & & & \\
\hline $10 \%$ Critical Value & -2.61 & -2.61 & & & \\
\hline Lag & LR & FPE & AIC & $\mathrm{SC}$ & HQ \\
\hline 0 & 290.12 & 290.12 & -3.72 & -3.40 & -3.61 \\
\hline 1 & 284.05 & $1.39 \mathrm{E}-14$ & -12.11 & $-9.57^{*}$ & -11.25 \\
\hline 2 & $74.45 *$ & $6.66 \mathrm{E}-15$ & -13.27 & -8.51 & -11.67 \\
\hline 3 & 55.83 & $3.39 \mathrm{e}-15^{*}$ & $-15.38^{*}$ & -8.40 & $-13.03 *$ \\
\hline
\end{tabular}

* Indicates lag order selected by the criterion 
Table 3 presents the results for the variables in levels and first difference for Phillipe Perron Test. This test confirmed the results that the series were stationary at first difference, so we proceeded with Co-integration tests. The estimation of Johnson and Juselius co-integration approach required that there should be appropriate lag selected for all estimation; for this purpose, unrestricted VAR was estimated. The results of VAR test are also reported in Table 3 above. Akaike information was used for this purpose and lag length determined by this criterion was 3.

Maximum likelihood based Johansen (1988; 1991) and Johansen and Juselius (1990) procedure was used to determine the presence of co-integration vectors in a set of non stationary time series. The first test was based on the trace statistic that tested the null hypothesis of $r$ co-integrating vectors against the alternative of $r$ more co-integrating vectors.

Table 4

Multivariate Co-Integration Trace Statistics

\begin{tabular}{ccccc}
\hline Hypothesized No. of CE(s) & Eigen Value & Trace Statistic & Critical Value & Prob.** \\
\hline None & 0.91 & 236.42 & 125.61 & 0.00 \\
At most 1 & 0.86 & 153.53 & 95.75 & 0.00 \\
At most 2* & 0.73 & 87.90 & 69.81 & 0.00 \\
At most 3 & 0.47 & 43.65 & 47.85 & 0.11 \\
At most 4 & 0.37 & 22.35 & 29.79 & 0.27 \\
At most 5 & 0.18 & 6.72 & 15.49 & 0.60 \\
At most 6 & 0.00 & 0.06 & 3.84 & 0.80 \\
\hline
\end{tabular}

Trace test indicates 3 co-integrating equations at the 0.05 level

Table 4 present the results of multivariate co-integration analysis. Trace test indicated that there existed co-integration among GDP per capita and workers' remittances, labor migration, unemployment, government expenditure, domestic savings, and human capital development at the 0.05 level. Trace test confirmed 3 co-integrating equations at 0.05 level. The Maximal Eigen-value test was used to test the null hypothesis that there were at most $\mathrm{r}$ co-integrating vectors against the alternative of $\mathrm{r}+1$ co-integrating vectors. Table 5 mentioned below reports the results of Max-Eigen-value test. This test also confirmed the presence of 3 co-integrating equations at 0.05 level. Therefore, the results of multivariate co-integration showed that there existed long-run relationship between economic growth and workers' remittances including other stated variables.

Table 5

Multivariate Co-Integration Analysis of Max-Eigen-Values

\begin{tabular}{ccccc}
\hline Hypothesized No. of CE(s) & Eigen Value & Max Eigen Statistic & Critical Value & Prob.** \\
\hline None & 0.91 & 82.89 & 46.23 & 0.00 \\
At most 1 & 0.86 & 65.63 & 40.08 & 0.00 \\
At most 2 & 0.73 & 44.25 & 33.87 & 0.00 \\
At most 3 & 0.47 & 21.29 & 27.58 & 0.25 \\
At most 4 & 0.37 & 15.63 & 21.13 & 0.24 \\
At most 5 & 0.18 & 6.66 & 14.26 & 0.52 \\
At most 6 & 0.00 & 0.06 & 3.84 & 0.80 \\
\hline
\end{tabular}


The results of bivariate co-integration are reported in Table 6 . The trace statistic at 5\% confidence interval in bivariate analysis results showed that there existed long-run relationship between economic growth and workers' remittances. Economic growth has long run relation with labor migration unemployment and government expenditure. Trace statistic indicated the long-run relationship between economic growth and human capital development and unemployment and workers' remittances. The trace statistic of bivariate analysis at $10 \%$ confidence interval showed that human capital development had long-run relation with workers' remittances.

Table 6

Bivariate Co-Integration Analysis

\begin{tabular}{|c|c|c|c|c|c|}
\hline & $\begin{array}{c}\text { Hypothesized No. } \\
\text { of CE(s) }\end{array}$ & Eigen Value & Trace Statistic & $\begin{array}{c}0.05 \text { Critical } \\
\text { Value }\end{array}$ & Prob.** \\
\hline \multirow[t]{2}{*}{ 1. GDP and Remittances } & GDP & 0.26 & 13.98 & 12.32 & 0.02 \\
\hline & $\mathrm{C}$ & 0.12 & 4.16 & 4.12 & 0.05 \\
\hline \multirow[t]{2}{*}{ 2. GDP and Labor Migration } & GDP & 0.27 & 13.06 & 12.32 & 0.03 \\
\hline & LMR & 0.08 & 2.79 & 4.12 & 0.11 \\
\hline \multirow[t]{2}{*}{ 3. GDP and Unemployment } & GDP & 0.28 & 13.38 & 12.32 & 0.03 \\
\hline & UEM & 0.07 & 2.60 & 4.12 & 0.12 \\
\hline \multirow[t]{2}{*}{ 4. GDP and Domestic Savings } & GDP & 0.21 & 9.25 & 12.32 & 0.15 \\
\hline & DS & 0.04 & 1.46 & 4.12 & 0.26 \\
\hline \multirow[t]{2}{*}{ 5. GDP and Government Expenditure } & GDP & 0.34 & 13.80 & 12.32 & 0.02 \\
\hline & GXP & 0.01 & 0.44 & 4.12 & 0.56 \\
\hline \multirow[t]{2}{*}{ 6. GDP and Human Capital Development } & GDP & 0.39 & 17.26 & 12.32 & 0.00 \\
\hline & HCD & 0.08 & 6.93 & 3.84 & 0.00 \\
\hline \multirow[t]{2}{*}{ 7. Remittances and Unemployment } & REM & 0.16 & 20.72 & 15.19 & 0.00 \\
\hline & UEM & 0.12 & 15.91 & 14.79 & 0.04 \\
\hline \multirow[t]{2}{*}{ 8. Remittances and Labor Migration } & REM & 0.11 & 5.45 & 12.32 & 0.50 \\
\hline & LMR & 0.05 & 1.71 & 4.12 & 0.22 \\
\hline \multirow[t]{2}{*}{ 9. Labor Migration and Unemployment } & LMR & 0.10 & 5.10 & 12.32 & 0.55 \\
\hline & UEM & 0.04 & 1.37 & 4.12 & 0.28 \\
\hline 10. Human Capital Development and Remittances & $\mathrm{HCD}$ & 0.09 & 3.10 & 4.12 & 0.09 \\
\hline
\end{tabular}

According to representation theorem, if two variables were co-integrated then Granger causality must exist in at least one direction. Results of Granger causality are reported in Table 7. Rejection of the null hypothesis at 5\% indicated that there existed unidirectional granger causality between workers' remittances and GDP. Workers' remittances were leading and economic growth was following. There existed unidirectional granger causality between labor migration and GDP and the null hypothesis was rejected at 5\%. In the same way, unidirectional Granger causality also exited between unemployment and economic growth (GDP per capita). There exited unidirectional Granger causality between GDP per capita and government expenditures. Here GDP was leading and government expenditures were following. Rejection of null hypothesis at 5\% showed that there existed bidirectional Granger causality between human capital development and GDP per capita. There existed unidirectional Granger causality between labor migration and workers' remittances. Here labor migration was leading and workers' remittances were following. Similarly, there existed unidirectional Granger causality between workers' remittances and unemployment level. In this case worker' remittances were leading and unemployment level was following. In the same way, there existed unidirectional 
Granger causality between unemployment level and labor migration. Here unemployment was leading and labor migration was following.

Table 7

Granger Causality Test

\begin{tabular}{lccc}
\hline \multicolumn{1}{c}{ Null Hypothesis } & Obs & F-Statistic & Prob. \\
\hline RREM does not Granger Cause RGDP & 32 & 5.20 & 0.00 \\
RGDP does not Granger Cause RREM & & 1.33 & 0.28 \\
RLMR does not Granger Cause RGDP & 32 & 3.54 & 0.03 \\
RGDP does not Granger Cause RLMR & & 0.27 & 0.84 \\
RUEM does not Granger Cause RGDP & 32 & 5.83 & 0.00 \\
RGDP does not Granger Cause RUEM & & 2.16 & 0.11 \\
RDS does not Granger Cause RGDP & 32 & 0.60 & 0.62 \\
RGDP does not Granger Cause RDS & & 0.61 & 0.61 \\
RGXP does not Granger Cause RGDP & 32 & 0.18 & 0.90 \\
RGDP does not Granger Cause RGXP & & 3.38 & 0.03 \\
RHCD does not Granger Cause RGDP & 32 & 3.63 & 0.02 \\
RGDP does not Granger Cause RHCD & 32 & 4.82 & 0.00 \\
RLMR does not Granger Cause RREM & & 6.83 & 0.00 \\
RREM does not Granger Cause RLMR & 32 & 0.55 & 0.64 \\
RUEM does not Granger Cause RREM & & 0.24 & 0.86 \\
RREM does not Granger Cause RUEM & 32 & 7.58 & 0.00 \\
RDS does not Granger Cause RREM & & 0.59 & 0.62 \\
RREM does not Granger Cause RDS & 32 & 0.95 & 0.42 \\
RGXP does not Granger Cause RREM & & 1.40 & 0.26 \\
RREM does not Granger Cause RGXP & 32 & 0.06 & 0.97 \\
RHCD does not Granger Cause RREM & & 1.25 & 0.31 \\
RREM does not Granger Cause RHCD & 32 & 1.27 & 0.30 \\
RUEM does not Granger Cause RLMR & & 2.88 & 0.05 \\
RLMR does not Granger Cause RUEM & & 0.32 & 0.80 \\
\hline
\end{tabular}

As a long-run connection has been documented between GDP per capita and workers' remittances including other set of variables, now we can look at the likelihood of a short-run relationship by using an ECM framework. The results of ECM are shown in Table 8. The error term is significant and $28 \%$ of disequilibrium is adjusted in one time period. The short run relationship coefficient of remittances and domestic savings with GDP per capita is significant and positive. Similarly, the short run relationship coefficient of labor migration, unemployment level and is significant and negative. The result of co-integration analysis, granger causality, and vector error correction model are consistent with the hypothesis formulated before the empirical results and findings. However, the result of empirical test does not provide any evidence of significant relationship between workers' remittances and human capital development. Comparably, VECM model test indicates that domestic savings have significant positive relation with GDP per capita; but the results of Granger causality test indicate no lead lag relationship of domestic saving with GDP per capita.

After analyzing the state of relationship between workers' remittance and economic growth along with other aspects, the recursive SME model was applied to see the impact of workers' remittances on economic growth through some major channels. As results in Table 3 showed all series have unit root one so OLS was applied to estimate the recursive SME model. Table 9 showed the results for consumption as dependent variable and worker's remittances as independent variable as per equation 1 . The result in Table 9 confirms that remittances had 
significant positive impact on the level of consumption in Pakistan. The explanatory power of the model was 40 percent shown by R-square. Table 9 shows the results with investment as dependent variable and worker remittances as independent variable as per Equation 2. The results in Table 9 show that worker's remittances had no impact on the level of investment in Pakistan. This was possible due to consumption oriented society of Pakistan. Therefore, mostly the amount remitted by migrant workers was spent on routine life consumption. Following this, Table 9 shows the results for GDP as dependent variable and predicted consumption (HC) and predicted investment (INV) as independent variables as per equation 3 .

Table 8

Vector Error Correction Model

\begin{tabular}{cccc}
\hline & Coefficient & SD & T Statistic \\
\hline RREM (-1) & 0.05 & 0.01 & 5.42 \\
RLMR (-1) & -0.11 & 0.04 & -2.51 \\
RUEM (-1) & -0.06 & 0.03 & -1.89 \\
RDS (-1) & 0.04 & 0.01 & 2.86 \\
RGXP (-1) & -0.37 & 0.03 & -10.56 \\
RHCD (-1) & -0.04 & 0.05 & -0.74 \\
Error Correction: & D(RGDP) & -0.28 Coefficient & \\
CointEq1 & & -0.13 SD & \\
& & -2.16 T Statistic & \\
\hline
\end{tabular}

The results in Table 9 show that household consumption had positive significant impact on economic growth in Pakistan. However, the predicted value of investment had insignificant impact on pace on economic growth in country. This is because money received by overseas workers' families was usually used for daily consumption because of consumption oriented characteristic of Pakistani society. As remittances direct impact on investment was insignificant so the predicted value of investment from workers' remittances also had no effect on the level of economic growth in the country. The explanatory power of this model was 37.1 percent as depicted by $\mathrm{R}$ square. Model was good fit as probability of $\mathrm{F}$ statistic was significant.

Table 9

Recursive Model Results

\begin{tabular}{ccccc}
\hline \multicolumn{5}{c}{ Impact of Workers' Remittances on Household Consumption } \\
\hline Variable & Coefficient & Std. Error & T-Stat & Prob. \\
\hline C & 71.07 & 1.33 & 53.31 & 0.00 \\
REM & 1.18 & 0.24 & 4.76 & 0.00 \\
R-Squared & 0.40 & & & \\
Adjusted R-Squared & 0.38 & & 0.00 \\
F-Statistic & 22.72 & Prob (F-Statistic) & Prob. \\
\hline \multicolumn{5}{c}{ Impact of Workers' Remittances on Investment } \\
\hline Variable & Coefficient & Std. Error & 0.00 \\
C & 16.67 & 0.66 & 25.06 & 0.61 \\
REM & 0.06 & 0.12 & 0.50 & \\
R-Squared & 0.07 & & & 0.005 \\
Adjusted R-Squared & 0.02 & & \\
F-Statistic & 3.24 & Prob (F-Statistic) & \\
\hline
\end{tabular}




\begin{tabular}{ccccc}
\hline \multicolumn{5}{c}{ Impact of Household Consumption and Investment on Economic Growth } \\
\hline Variable & Coefficient & Std. Error & T-Stat & Prob. \\
$\mathrm{C} \wedge$ & 164.06 & 92.48 & 1.77 & 0.08 \\
$\mathrm{HC}$ & 74.71 & 17.87 & 4.18 & 0.00 \\
$\mathrm{INV}$ & 66.16 & 52.37 & 1.26 & 0.216 \\
R-Squared & 0.37 & & & 0.00 \\
Adjusted R-Squared & 0.32 & & & \\
F-Statistic & 8.86 & Prob (F-Statistic) & & \\
\hline
\end{tabular}

\section{Discussion}

This study looks into the association between workers' remittances and economic growth in Pakistan by using the time series data for period of 1975 to 2010. The results of co-integration analysis confirm that there exists significant long-run relationship between the workers' remittances and economic growth in Pakistan. The Vector Error correction model analysis proves that there exist positive significant relationship between workers' remittances and pace of economic growth in country in short run. Unemployment and government expenditure has significant negative relationship with economic growth in short run.

Granger causality results prove that unidirectional causality exists between workers' remittances and economic growth. Workers' remittances are leading and economic growth is following. Therefore, this analysis confirms that inflow of migrants' remittances cause the economic growth in Pakistan. Unidirectional granger causality also exists between labor migration and economic growth. Similarly, workers' remittances granger causes the unemployment level. Because of positive impact of workers' remittances on production and economic activity level in the country, workers' remittances surely contribute to lower the unemployment rate in the country. Granger causality also confirms that there exists unidirectional causality between unemployment and labor migration. Here unemployment is leading and labor migration is following. This means unemployment in home country induce the labor migration beyond country border.

Recursive OLS estimates revealed that workers' remittances have significant positive impact on consumption and consumption in turn positively affects the economic growth. However, remittance impact on investment is insignificant and in turn investment has no impact on pace of economic growth in Pakistan. This is due to consumption oriented society of Pakistan. Thus, workers' remittances impact on economic growth is flowing through consumption rather than investment. As study results reveal and regarding the long-run and short-run relationship between workers' remittances and economic growth, it is crucial to implement more striking policies that would induce the Pakistanis living abroad to remit more funds home to keep up the pace of economic growth of the country. Policies to consider in this regard should focus on reduction in the cost of international money transfers, and enhancement of the efficiency and reliability of international money transfer mechanisms.

\section{Conclusion}

On basis of results of the study, it is suggested that Pakistan government should form friendly policy to ensure the uninterrupted and increased inflows of workers' remittances and their efficient utilization to ensure economic growth. The overseas Pakistani should be given 
incentives to make investment in home country so that long-run effect of workers' remittance could be ensured and enhanced. The emigration policy should be devised in a way that make emigration venture less costly. Therefore, that idle labor force can migrate easily beyond country border to find suitable jobs. In this way, the average labor productivity will rise and in country and labor force working abroad will provide the much needed stream of foreign exchange reserves. As a result, the pace of economic growth will go up.

This study analyzes the relationship between workers' remittances and economic growth along with the interaction between workers' remittances and unemployment level in the Pakistan. Future research can be conducted to quantify the impact of workers' remittance on economic growth in Pakistan as well as in south Asia. The cross country study on this area will shed light on the fact that how different economies in south Asian region individually and jointly respond to inflow of workers' remittances. Analysis of group and individual behavior of remittances impact will provide the comparative view and it will be helpful for every country to formulate the better policies and to induce increased level of workers' remittances and their effective utilization.

\section{References}

Adams, R. H., \& Page, J. (2005). Do international migration and remittances reduce poverty in developing countries? World Development, 33(10), 1645-1669.

Adams, S., \& Klobodu, E. K. M. (2016). Remittances, regime durability and economic growth in Sub-Saharan Africa (SSA). Economic Analysis and Policy, 50, 1-8.

Addison, E. K. Y. (2004). The macroeconomic impact of remittances in Ghana. Director of Research Department, Bank of Ghana, Ghana.

Adenutsi, D. E. (2011). Financial development, international remittances and endogenous growth in Ghana. Studies in Economics \& Finance, 28(1), 68-89.

Ahmed, J., Zaman, K., \& Shah, I. A. (2011). An empirical analysis of remittances-growth nexus in Pakistan using bond testing approach. Journal of Economics \& International Finance, 3(3), 176-186.

Ahortor, C. R. K., \& Adenutsi, D. E. (2009). The impact of remittances on economic growth in small open developing economies. Journal of Applied Sciences, 9(18), 3257-3286.

Airola, J. (2007). The use of remittance income in Mexico. Journal of International Migration Review, 41(4), 850-859.

Arun, T., \& Ulku, H. (2011). Determinants of Remittances: The Case of the South Asian Community in Manchester. Journal of Development Studies, 47(6), 894-912.

Azam, M., \& Khan, A. (2011). Workers' remittances and economic growth: Evidence from Azerbaijan and Armenia. Global Journal of Human Social Sciences, 11(7), 41-46.

Barai, M. K. (2012). Development dynamics of remittances in Bangladesh. Sage Open, 2(1), 1-13.

Buckley, C., \& Hofmann, E. T. (2012). Are remittances an effective mechanism for development? Evidence from Tajikistan. Journal of Development Studies, 48(8), 1121-1138.

Campbell, T. (2006). The long and short-run determinants of workers' remittances to Barbados. Journal of Savings \& Development, 30(3), 297-308.

Catrinescu, N. M., Leon Ledesma, M., Piracha, M., \& Quillin, B. (2009). Remittances, institution, and economic growth. World Development, 37(1), 81-92.

Chowdhury, M. (2016). Financial development, remittances and economic growth: Evidence using a dynamic panel estimation. margin: The Journal of Applied Economic Research, 10(1), 35-54.

Das, A., \& Chowdhury, M. (2011). Remittances and GDP dynamics in 11 developing countries: Evidence from panal cointegration and PMG techniques. Romanian Economic Journal, 14(42), 3-23.

De Haas, H. (2005). International migration, remittances, and development: Myths and facts. Third World Quarterly, 26(8), $1269-1284$. 
Fayissa, B., \& Nsiah, C. (2008). The impact of remittances on economic growth and development of Africa (Working Paper Series). Retrieved from Middle Tennessee State University website www.mtsu.edu/econfin/docs/working-papers

Fayissa, B., \& Nsiah, C. (2010). Can remittances spur economic growth and development? Evidence from Latin American countries (LACs) (Working Paper Series). Retrieved from Middle Tennessee State University website www.mtsu.edu/econfin/docs/working-papers

Gammage, S. (2006). Exporting people and recruiting remittances: A development strategy for El Salvador. Latin American Perspectives, 33(6), 75-100.

Georges, A., \& Pozo, S. (2010). Migration, remittances, and children's schooling in Haiti. The Annals of the American Academy of Political \& Social Science,630(1), 224-244.

Giuliano, P., \& Ruiz-Arranz, M. R. (2009). Remittances, financial development and Growth. Journal of Development Economics, 90, 144-152.

Glytsos, N. P. (2005). The Contribution of remittances to growth: A dynamic approach and empirical analysis. Journal of Economic Studies, 32(6), 468-496.

Imai, K. S., Gaiha, R., Ali, A., \& Kaicker, N. (2014). Remittances, growth and poverty: New evidence from Asian countries. Journal of Policy Modeling,36(3), 524-538.

Abdus, S., \& Zafar, I. (2005). The Contribution of Workers' Remittances to Economic Growth in Pakistan (Working Paper No. 187). Retrieved from Pakistan Institute of Development Economics website http://www.pide.org.pk/Research/Report187.pdf.

Jackman, M., Craigwell, R., \& Moore, W. (2009). Economic volatility and remittances evidence from SIDS. Journal of Economic Studies, 36(2), 135-146.

Jawaid, S. T., \& Raza, S. A. (2012). Workers' remittances and economic growth in China and Korea: An empirical analysis. Journal of Chinese Economics \& Foreign Trade Studies, 5(3), 185-193.

Jawaid, S. T., \& Waheed, A. (2011). Effects of term of trade and its volatility on economic growth: A cross country empirical investigation. Journal World Transition Economy Research, 18, 217-229.

Jebran, K., Abdullah, A., Iqbal, A., \& Ullah, I. (2016). Effects of remiitances on per capita economic growth of Pakistan. Pakistan Business Review, 18(1), 1-8.

Johansen, S. (1988). Statistical analysis of cointegration vectors. Journal of Economic Dynamics \& Control, 12, $231-254$.

Johansen, S., \& Juselius, K. (1990). Maximum likelihood estimation and inference on cointegration: With applications to the demand for money. Oxford Bulletin of Economic \& Statistics, 52, 169-210.

Johansen, S. (1991). Estimation and hypothesis testing of cointegration vectors in Gaussian vector autoregressive models. Econometrica, 59, 1551-1580.

Johnson, A. O. (2011). Human capital development and economic growth in Nigeria. European Journal of Business \& Management, 3(9), 29-38.

Jongwanic, J. (2007). International Migration and Economic Development: Lesson from low Income Countries. UK: Edward Elgar Cheltenham.

Karagoz, K. (2009). Workers' remittances and economic growth: Evidence from Turkey. Journal of Yasar University, 4(13), $1891-1908$.

Khan, M. S. (2005). Human capital and economic growth in Pakistan. The Pakistan Development Review, 44(4), $455-478$.

Kratou, H., \& Gazdar, K. (2016). Addressing the effect of workers' remittance on economic growth: Evidence from MENA countries. International Journal of Social Economics, 43(1), 51-70.

Maimbo, S. M. (2006). Remittances and economic development in Somalia (Working Paper No. 38). Retrieved from World Bank website http://www.worldbank.org/conflict

Niimi, Y., Pham, T. H., \& Reilly, B. (2009). Determinants of remittances: Recent evidence using data on internal migrants in Vietnam. Asian Economic Journal, 23(1), 19-39.

Nishat, M., \& Bilgrami, N. (1991). The Impact of migrant worker's remittances on Pakistan economy. Pakistan Economic \& Social Review, 29(1), 21-41.

Posso, A. (2012). Remittances and aggregate labor supply: Evidence from sixty-six developing nations. Journal of Developing Economies, 50(1), 25-39.

Rahman, M., Mustafa, M., Islam, A., \& Gharana, K. K. (2006). Growth and employment empirics of Bangladesh. The Journal of Developing Areas, 40(1), 99-114. 
Ratha, D. (2005). Workers' remittances: An important and stable source of external development finance (Working Paper No. 9). Retrieved from World Bank website http://repository.stcloudstate.edu/econ seminars/9

Shahbaz, M. (2010). Income inequality-economic growth and non-linearity: A case of Pakistan. International Journal of Social Economics, 37(8), 613-636.

Wong, H. T. (2010). Term of trade and economic growth in Japan and Korea: An empirical analysis. Empirical Economics, 38, $139-158$.

Yasmeen, K., \& Anjum, A., Ambreen, S., \& Twakal, S. (2011). The impact of workers' remittances on private investment and total consumption in Pakistan. International Journal of Accounting \& Financial Reporting, 1(1), 152-160.

Zuniga, M. C. (2011). On the path to economic growth, do remittances help? Evidence from panel VARs. The Developing Economies, 49(2), 171-202. 